\title{
Back to the future: tobacco industry interference, evidence and the Framework Convention on Tobacco Control
}

\author{
Melanie Wakefield, ${ }^{1}$ Jonathan Liberman ${ }^{2}$
}

The publication of a special communication by Ronald Davis in this issue (see page 211) ${ }^{1}$ about a report on the effect of tobacco advertising bans ("the Boddewyn report") that was in fact ghost-written by British American Tobacco caused one of us to experience a memory flashback to the mid-1980s. At that time, MW was working as a research officer in a state health department in Adelaide, South Australia. I (MW) distinctly remember being given the Boddewyn report to provide comment on to my health minister's office. Even though I was then an inexperienced researcher, I could see that the report was seriously flawed. Because it was apparently the work of such a prestigious-sounding individual and organisation, I became deeply concerned that it could actually influence government policy. I prepared several pages of critique pointing out the problems with the report, added a concise summary, and sent it back up to the minister's office. I received no further requests about the report, but it was the first time I was shocked by the extent of misinformation from sources allied with the tobacco industry. That situation was one of several that drew me more closely into a career in tobacco control research.

While it is no longer new news that the tobacco industry promotes misinformation about tobacco advertising restrictions in order to protect its commercial interests, ${ }^{2-5}$ the discovery that a major report on tobacco advertising bans published by the International Advertising Association (IAA) was in fact ghost-written by someone from a tobacco company is truly outrageous, and leads to the question of

\footnotetext{
${ }^{1}$ Centre for Behavioural Research in Cancer, The Cancer Council Victoria, Melbourne, Australia; ${ }^{2}$ VicHealth Centre for Tobacco Control and the Framework Convention Alliance for Tobacco Control, Melbourne, Australia

Correspondence to: Melanie Wakefield, Centre for Behavioural Research in Cancer, The Cancer Council Victoria, Melbourne, Australia; melanie.wakefield@ cancervic.org.au
}

what other "expert" reports from advertising association or allied sources might have travelled a similar route. Even now, the website of the IAA features a position statement, issued in September 2007, indicating that it opposes attempts to restrict or ban tobacco advertising, because "experience in countries where the advertising for products has been banned shows that reducing or banning advertising will not reduce rates of consumption. Ad bans do not work..." (http://www.iaauae.org/en/category/ resource-library/position-statements/ (accessed 16 March 2008)). On the contrary, peer-reviewed expert scientific reports conclude that there is robust evidence that tobacco advertising and promotion increase youth smoking uptake and progression to regular tobacco use. $^{67}$ In addition, carefully conducted peerreviewed studies and reports demonstrate that comprehensive tobacco advertising bans reduce tobacco consumption, when other important influences such as tobacco price, income and employment are taken into account. ${ }^{8}$ However, partial advertising bans have little effect on consumption because companies simply shift marketing expenditures from the banned media to other permitted forms of marketing. ${ }^{\text {? }}$

Unlike the positions of the tobacco and advertising industries, tobacco control has come a long way since the 1980s. We now have an international treaty, the Framework Convention on Tobacco Control (FCTC), ${ }^{9}$ unimaginable 20 years ago when the Boddewyn report was first doing the rounds. The FCTC has become one of the most rapidly embraced treaties in history. As of writing, just over 3 years after coming into force, it had 152 parties signed up. The global community has now well and truly spoken.

The Foreword to the FCTC correctly describes it as an "evidence-based treaty". Parties to the FCTC, recognizing the evidence, have undertaken legal obligations to adopt the measures that are effective in reducing tobacco consumption, including taxation (and associated antiillicit trade measures), protection against second-hand smoke, health warnings, bans on advertising, promotion and sponsorship and public education programs. A junior researcher working in a health department today receiving a piece of tobacco industry propaganda will be in a very different situation from that in which MW found herself in the mid-1980s, because he or she will be able to pick up a copy of the FCTC. On the subject matter of the Boddewyn report, he or she will be able to point immediately to Article 13 of the Convention, which deals with tobacco advertising, promotion and sponsorship, and begins with the statement: "Parties recognize that a comprehensive ban on advertising, promotion and sponsorship would reduce the consumption of tobacco products",

That the global community has spoken so clearly through a text that has binding force in international law does not, of course, mean that the tobacco industry and its allies will stop producing and distributing "Boddewyn-like" reports. But those who have to respond to these reports should now be well armed.

In addition to the text of the FCTC, Parties are in the process of developing guidelines on implementation, which aim to provide advice on the best ways of implementing obligations under the Convention. At the second session of the Conference of the Parties (COP), held in June/July 2007 in Bangkok, Thailand, the COP adopted strong guidelines on Article 8 (protection against exposure to tobacco smoke; http://www.who.int/gb/fctc/PDF/ cop2/FCTC_COP2_DIV9-en.pdf). At the third session of the COP, to be held in South Africa in November 2008, the COP will have before it draft guidelines on Articles 5.3 (protection of tobacco control policies from the commercial and other vested interests of the tobacco industry), 11 (packaging and labelling) and 13 (advertising, promotion and sponsorship).

It is essential for global tobacco control that guidelines on each of these Articles set strong standards for implementation. What governments and tobacco control advocates working towards FCTC implementation need are clear evidence-based guidelines that can be readily implemented, and that can be waved in the face of the tobacco industry when it comes knocking with its obfuscation and misinformation, as it inevitably will. Guidelines on Articles 11 and 13 should assist governments in implementing best practice laws and policies on packaging 
and labelling, and tobacco advertising, promotion and sponsorship. Guidelines on Article 5.3 should assist governments in implementing best practice laws and policies that will keep the tobacco industry from interfering with tobacco control policy-making and implementation. Effective guidelines on Article 5.3 will help protect governments from the tobacco industry not only when it comes knocking itself, but also when it sends (and invariably pays) others to do its business for it.

Competing interests: None.

Tobacco Control 2008;17:145-146. doi:10.1136/tc.2008.025791

\section{REFERENCES}

1. Davis RM. British American Tobacco ghost-wrote reports on tobacco advertising bans by the International Advertising Association and JJ Boddewyn. Tob Control. 2008;17:211-14.

2. Yach D, Bettcher D. Globalisation of tobacco industry influence and new global responses. Tob Control 2000:9:206-16.

3. Hammond R, White C. Multinational tobacco industry activity in the Middle East: a review of internal industry documents. In: Voice of Truth. Vol. 1. Cairo, Egypt: World Health Organisation, Regional office for the Eastern Mediterranean, 2001; http://www.emro.who. int/tfi/VOICE\%200F\%20TRUTH.pdf laccessed 20 April 2008)

4. Neuman M, Bitton A, Glantz S. Tobacco industry strategies for influencing European Community tobacco advertising legislation. Lancet 2002;359:1323-30.

5. Szilagy T, Chapman S. Tobacco industry efforts to erode tobacco advertising controls in Hungary. Cent Eur J Public Health 2004;12:190-6.
6. US Department of Health and Human Services. Preventing tobacco use among young people: a report of the Surgeon General. Atlanta, Georgia, USA: US Department of Health and Human Services, Public Health Service, Centers for Disease Control and Prevention, National Center for Chronic Disease Prevention and Health Promotion, Office on Smoking and Health, 1994.

7. National Cancer Institute. The role of the media in promoting and reducing tobacco use. Tobacco Control Monograph no.19. Bethesda, Maryland, USA: US Department of Health and Human Services, Nationa Cancer Institute, National Institutes of Health, (in press)

8. Saffer H, Chaloupka FJ. The effect of tobacco advertising bans on tobacco consumption. $J$ Health Econ 2000;19:1117-37.

9. World Health Organization. WHO framework convention on tobacco control. Geneva, Switzerland: World Health Organization, 2003 http://www.who.int/ tobacco/framework/WHO_FCTC_english.pdf laccessed 20 April 2008).

\section{BMJ Publishing Group}

\section{Applications are invited for the post of Editor}

\section{Tobacco Control}

Tobacco Control the leading international journal in its field publishing research and analysis on all aspects of tobacco use worldwide (Impact Factor 2.797). We now seek an editor who can maintain and improve its scientific and international reputation while maintaining its relevance to public health professionals, epidemiologists and activists.

Applications from suitably qualified and experienced specialists with an active interest in combating tobacco use are invited. Joint applications from two or more individuals willing to act as a team are welcomed.

Full editorial support and training will be provided. The successful applicant(s) will be free to select his/her own team of associate editors and board members.

Closing date for applications is 31st July 2008. Interviews will be held in August/September 2008. It is envisaged that the outgoing editors will hand over late in 2008 and the successful candidate will officially take up the post of editor in January 2009.

Further details of the post can be discussed with outgoing editor Simon Chapman (sc@med.usyd.edu.au) or the publishing director, Mr Peter Ashman (see below); a job description is available on request.

Applications (including a full CV and a critique of the journal) should be sent to Mr Peter Ashman, BMJ Publishing Group, BMA House, Tavistock Square, London WC1H 9JR, UK. Tel +44 (0)20 7383 6169. Fax +44 (0)20 73836668 . Email ctorselli@bmjgroup.com 